\title{
Biogas production supported by excess heat - A systems analysis within the food industry
}

Sarah Broberg and Emma Lindkvist

The self-archived postprint version of this journal article is available at Linköping University Institutional Repository (DiVA):

http:/ / urn.kb.se/ resolve?urn=urn:nbn:se:liu:diva-114983

N.B.: When citing this work, cite the original publication.

Broberg, S., Lindkvist, E., (2015), Biogas production supported by excess heat - A systems analysis within the food industry, Energy Conversion and Management, 91, 249-258.

https:// doi.org/ 10.1016/j.enconman.2014.12.017

Original publication available at:

https:/ / doi.org/ 10.1016/j.enconman.2014.12.017

Copyright: Elsevier

http:// www.elsevier.com/

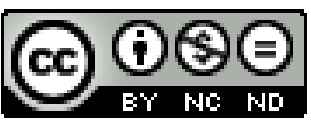




\title{
Biogas production supported by excess heat
}

\section{- A systems analysis within the food industry}

\author{
Sarah Broberg Viklund ${ }^{\mathrm{a}, *}$, Emma Lindkvist ${ }^{\mathrm{a}, \mathrm{b}}$ \\ ${ }^{a}$ Department of Management and Engineering, Division of Energy Systems, Linköping University, SE-581 83 \\ Linköping, Sweden \\ bBiogas Research Center, Linköping University, Sweden \\ ${ }^{*}$ Corresponding author: Department of Management and Engineering, Division of Energy Systems, Linköping \\ University, SE-581 83 Linköping, Sweden. E-mail address: sarah.broberg.viklund@liu.se. Phone number: +46 \\ 13281103
}

\section{ABSTRACT}

The aim of this paper was to study the effects on greenhouse gases and economics when a change is made in the use of industrial organic waste from external production and use of biogas (A) to internal production and use (B). The two different system solutions are studied through a systems analysis based on an industrial case. The baseline system (A) and a modified system (B) were compared and analysed. Studies show that industrial processes considered as integrated systems, including the exchange of resources between industries, can result in competitive advantages. This study focuses on the integration of internally produced biogas from food industry waste produced by a food company and the use of excess heat. Two alternative scenarios were studied: (1) the use of available excess heat to heat the biogas digester and (2) the use of a part of the biogas produced to heat the biogas digester. This study showed that the system solution, whereby excess heat rather than biogas is used to heat the biogas digester, was both environmentally and economically advantageous. However, the 
valuation of biomass affects the magnitude of the emissions reduction. Implementing this synergistic concept will contribute to the reaching of European Union climate targets.

Keywords: systems analysis, biogas production, industrial excess heat, climate impact, investment opportunity, synergies

\section{Introduction}

The European Union (EU) has set climate targets for the reduction of greenhouse gas (GHG) emissions, as well as for an increased share of renewable energy and the reduced use of primary energy. GHG emissions are targeted to be reduced by $20 \%$ by 2020 , relative to $1990^{1}$ levels [1], and $20 \%$ of the total share of the energy used in the EU should originate from renewable sources. Also, the use of primary energy should be reduced by $20 \%$, based on a projected level for 2005, coming through energy efficiency measures [2]. The Energy Efficiency Directive establishes a framework of measures that promote energy efficiency and the directive identifies recovery of industrial excess heat as one way to reach the EU target [3]. Broberg and Karlsson [4], Broberg Viklund and Johansson [5], Campana, Bianchi et. al. [6], and Thekdi and Belt [7] all analyse and discuss recovery of excess heat and concludes that the use of this heat resource may result in a reduced demand for primary energy, reduced GHG emissions, and increased economic gains; hence, it is an important measure for reaching the EU targets on reduced GHG emissions and energy efficiency.

Given growing concerns about climate change and increasing energy prices, the need for energy efficiency measures has become more important and a major issue for industry. In recent years interest in industrial cooperation has increased. Studies show that when industrial processes are considered integrated systems that include the exchange of resources (e.g.

\footnotetext{
${ }^{1}$ The 1990 level of EU total GHG emissions was approximately 5700 Mton $\mathrm{CO}_{2}$-equivalents.
} 
energy, by-products) between industries, competitive advantages can result. It is claimed that these advantages will have positive effects on the amount of resources used and of waste and pollutants generated by industries [8]. Fatih Demirbas, Balat et. al. [9] reviews the possibilities of using biowastes, such as industrial organic wastes, for biofuels production and shows the breadth of technologies. Martin and Eklund [10] discuss how to improve the environmental performance of biofuel production by exploiting various opportunities for synergy. Such collaboration can take different forms: by-product synergies allow for the use of by-products generated during a production process and utility synergies involve sharing energy (e.g. excess heat use). Tufvesson, Lantz et. al. [11] performed a life cycle assessment of biogas production for vehicle fuel from industrial residues, using a system expansion whereby the residues could (as today) be used as animal feed. The study showed reduced GHG emissions in biogas systems compared to the emissions from fossil fuel systems. The importance of systems analysis was highlighted in that study, since the choice of system boundary affected the environmental benefits of biogas production. Previous research has investigated the integration of biogas production in different industrial sectors with regard to sustainability and economic factors. Ellersdorfer and Weiss [12] studies the integration of a biogas plant with the building materials industry, and Traversi, Bonetta et. al. [13] analyse the integration of anaerobic digestion and milk and dairy production. However, there is a need to view biogas production in the industrial sector from a systems perspective. Biogas can be produced and used externally (e.g. as biogas for transportation, as fuel in a district heating (DH) system) or internally within the industry itself. Internal ${ }^{2}$ biogas production may offer a use for low-temperature industrial excess heat, which is an unused resource, and hence reduce the need for other fuels to heat a digester to its required temperature.

\footnotetext{
${ }^{2}$ The use of the term internal biogas production in this paper refers to biogas production at the industry where the organic waste is generated.
} 
The aim of this paper was to study the change from:

A) external production and use of biogas (baseline system)

to

B) internal production and use of biogas (modified system).

Internal biogas production offers the possibility of using excess heat to cover the demand for heat associated with biogas production. The study addressed the effects on GHG emissions and economics, along with the effects of the valuation of emissions connected with biomass. This is studied through a systems analysis based on a case (a food company), by comparing and analysing the differences between the two systems solutions (A and B) for the use of industrial organic waste:

A brief background to biogas production in the food industry together with a description of the industrial case studied is given in the background section. Thereafter methods used for this article are presented; this includes an introduction of the general systems approach applied in the study (Section 3.1) and a presentation of the environmental assessment and economic evaluation (Section 3.3 and 3.4) that the systems analysis is based on. This is followed by Section 4, where the data retrieved in the study are applied to the systems studied, together with a presentation of the assumptions made. The results are presented in Section 5 followed by a concluding discussion. 


\section{Background}

\subsection{Biogas production in the food industry}

Residues from the food industry can be used to produce biogas. This offers a way to reduce the amount of waste from the food industry, recover energy through anaerobic digestion, and replace fossil fuels. Currently, only a few industries in Sweden produce biogas at the industrial site [14]. Linné, Ekstrandh et. al. [15] found, in their inventory of the quantities of raw materials suitable for biogas production from different sectors in Sweden, that some food residues are used as raw materials in the production of animal feed. As a result, they presented the biogas potential of food residues in two scenarios: one that included the residue currently used for animal feed production and one that excluded it. The estimated biogas potential from the Swedish food industry presented in that study was approximately $1790 \mathrm{GWh} /$ year and 890 GWh/year, respectively [15]. In 2012, biogas production in Sweden totalled approximately $1590 \mathrm{GWh}$ [14]. Since a large share of the residues from the food industry is currently not used in biogas production, the biogas potential associated with the food industry is significant.

Biogas can be used as fuel to produce heat, as fuel in a combined heat and power plant (CHP plant), and/or as vehicle fuel [16]. The gas is produced when organic compounds are digested by microorganisms in an anaerobic environment. The composition of biogas varies depending on the substrate, but the main components are $\mathrm{CH}_{4}$ and $\mathrm{CO}_{2}$ [17]. Different substrates have different gas yields $[18,19]$, and different substrates can be digested together to achieve a more stable and effective biogas production process [15]. The production temperature ranges between $0^{\circ} \mathrm{C}$ and $65^{\circ} \mathrm{C}$, most commonly between $15^{\circ} \mathrm{C}$ and $65^{\circ} \mathrm{C}$ [17]. A higher production temperature results in a faster process and higher biogas yield, but more energy is required to produce the heat the process requires [20]. Heat from the combustion of biogas at the facility 
is normally used to heat the digester [21], however, external heat (e.g. industrial excess heat) can also be used by connecting the digester to an external supply through a heat exchange system [17].

The food industry, like other industries, generates excess heat that in many cases is not used. Studies investigating the potential of this excess heat are not comprehensive, and the industry's heterogeneous nature makes the excess difficult to estimate. In a study examining the potential of low-temperature excess heat $\left(20^{\circ} \mathrm{C}-50^{\circ} \mathrm{C}\right)$ in Swedish industries, the potential in the food industry was estimated at 2 TWh per year; however, the authors underline the uncertainty of that figure [22]. Ammar, Joyce et. al. [23] discusses the potential for reducing the environmental impact by using low-grade excess heat, noting the importance of taking a holistic view and the positive synergistic effects of using food industry waste in conjunction with low-grade heat for biofuel production.

\subsection{The system studied}

The food company ${ }^{3}$ in the studied case presented in this paper is Sweden's largest producer of mayonnaise-based salads, especially salads with potatoes and beetroots. The production site is located 32 kilometres from the nearest town and has 40 employees. Its annual energy use is approximately $8 \mathrm{GWh}$, split between oil $^{4}$ (75\%) and electricity (25\%). Oil is delivered from a depot and used to produce steam in a boiler; the steam is used in different production processes (e.g. to peel and boil potatoes). Oil is also used to heat the production premises and electricity to heat the offices. Excess heat is, for instance, generated from boiling and blanching potatoes. This unused heat resource may be used to fulfil the heat requirements associated with biogas production.

\footnotetext{
${ }^{3}$ The company name has been anonymized throughout the paper at the request of the company.

${ }^{4}$ Oil refers to light fuel oil.
} 
The organic waste generated at the company is currently mainly used to produce biogas at an external biogas plant (upgraded to vehicle fuel) and at a wastewater treatment plant ${ }^{5}$ (WWTP) (used as fuel in the DH system). The food company bears the costs of transporting the waste to the external biogas plant and to the WWTP (see Table 1). A small share of the organic waste is left outside the production building and to be retrieved free of charge by local farmers, who use it as animal feed. Data regarding transportation can be seen in Table 1.

Table 1 Data regarding transport of organic waste and oil to and from the production site (November 2012October 2013).

\begin{tabular}{|l|l|l|}
\hline & $\begin{array}{l}\text { Distance per } \\
\text { pickup/delivery } \\
\text { (return), km }\end{array}$ & $\begin{array}{l}\text { Number of } \\
\text { shipments }\end{array}$ \\
\hline WWTP & 64 & 51 \\
\hline External biogas & 80 & 77 \\
\hline plant & & \\
\hline Oil depot & 70 & 16 \\
\hline
\end{tabular}

Next to the food company $(<100 \mathrm{~m})$ is a farm with 250 pigs and where approximately 6000 pigs are bred annually. Each year, $3000 \mathrm{~m}^{3}$ of liquid pig manure (hereafter, manure) is generated at the farm; currently, the manure is spread on the farm's fields as fertilizer. This manure may instead be used as a substrate in biogas production.

\section{Methodology}

The system approach constitutes the general methodology for the study. The systems analysis is based on an environmental assessment and an economic evaluation. The data that forms the

\footnotetext{
${ }^{5}$ This is also an external biogas plant, but to be able to distinguish between the two, this one is referred to as WWTP in this study.
} 
basis of this analysis were retrieved from company records and through personal communication.

\subsection{System study}

Applying a system approach, when studying a change in a system, provides an opportunity to get a holistic picture of the effects of that change [24]. In this study, two different systems solutions were used to calculate and analyse the effects of the change on global GHG emissions and economics. The two systems solutions are shown schematically in Figure 1. The baseline system (Figure 1A) reflects the present situation, and the modified system (Figure 1B) envisions a situation in which the food company uses the organic waste in an internal biogas plant and produces biogas as a substitute for oil. Excess heat or biogas is used to heat the digester. In this modified system, the nearby pig farm also supplies the biogas plant with manure as a substrate in exchange for digestate to spread on its fields, instead of manure. 

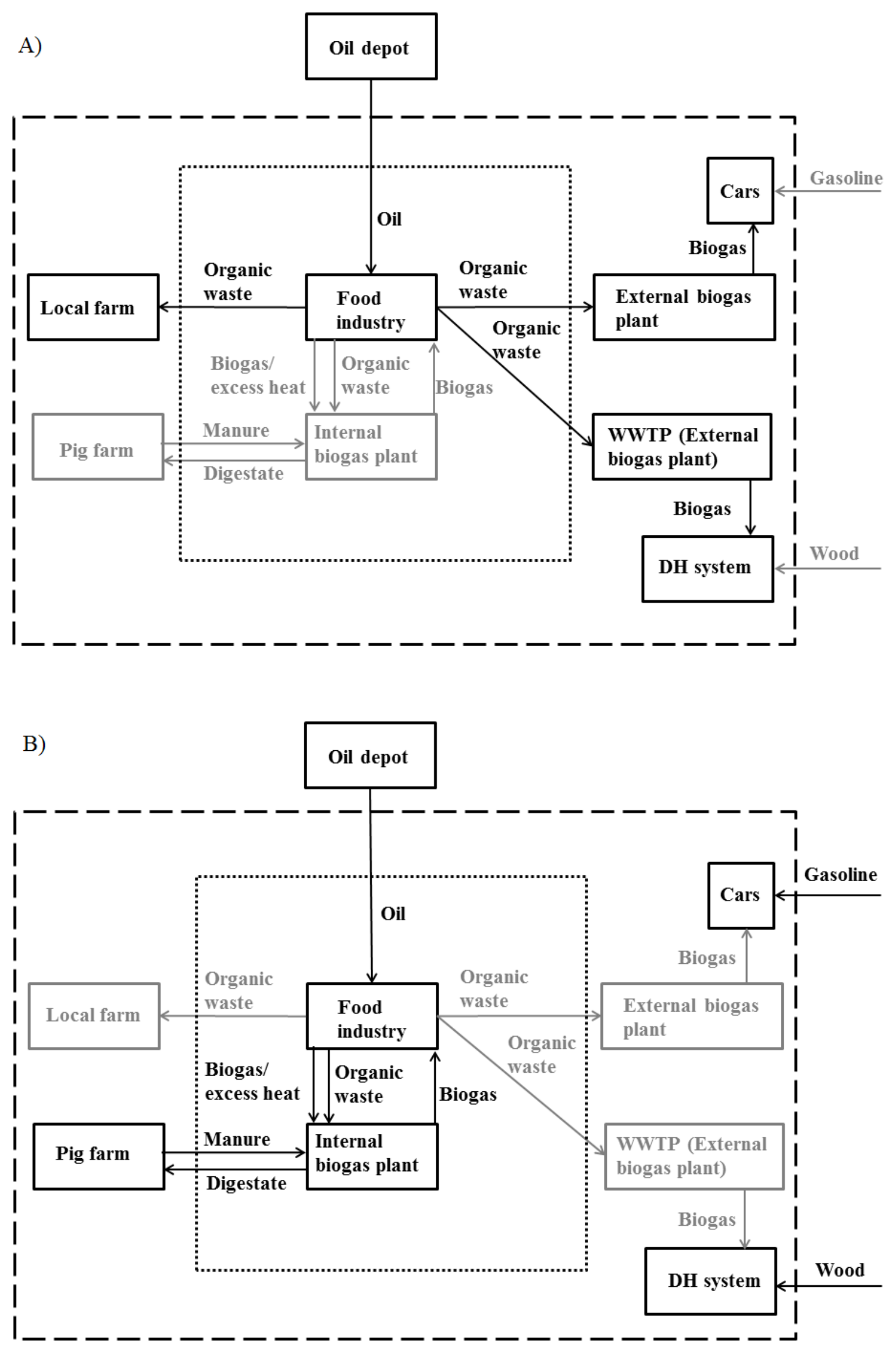
Figure 1 A) Baseline system B) Modified system. The dashed lines represent the system boundary regarding GHG emissions and the dotted lines represent the system boundary regarding economics. The parts in grey represent the differences between the systems.

\subsection{Data collection}

Data collection took place over one year, from November 2012 until October 2013. Several sources were used to estimate the amount of organic waste generated at the food company. The product yield could be calculated from the production data ${ }^{6}$, and the amount of raw material that did not end up in the finished product was determined from the product yield. The amount of organic waste was verified against the available invoices for transferring waste to the WWTP and external biogas plant. The invoices also provided information regarding the number of collections, collection costs, and the cost of oil. Data regarding the company's energy use were derived from the company’s energy logging system, Eneas Energy. The logging system provides information regarding oil use (by hour) and outdoor temperature. The amount of available excess heat was estimated based on the energy logging data, the available energy audit report [25], and the report on recycling solution for the boiler [26]. Data were also collected through personal communications during visits at the WWTP and the external biogas plant, as well as through visits and regular contact with the food company. The contacts at the different sites had positions such as environmental manager, production manager and chief executive officer.

\subsection{Environmental assessment}

To assess the GHG emissions of a system, the global warming potential (GWP) of the emissions can be studied. GWP-100 indicates the global warming potential of gases compared to $\mathrm{CO}_{2}$ in a time frame of 100 years. In this study $\mathrm{CO}_{2}, \mathrm{CH}_{4}$, and $\mathrm{N}_{2} \mathrm{O}$ are considered. The

\footnotetext{
${ }^{6}$ Production data consist of an excel document where information about the amount of raw materials, wastes and end products etc. is documented for each production day at the food company.
} 
GWP-100 of $\mathrm{CH}_{4}$ is 25 times greater than that of $\mathrm{CO}_{2}$; and that of $\mathrm{N}_{2} \mathrm{O}$ is 298 times greater than that of $\mathrm{CO}_{2}$.

Emission factors (EF) for the system studied were retrieved from the Intergovernmental Panel on Climate Change’s (IPCC) 2006 Guidelines for National Greenhouse Gas Inventories [27]. The direct emissions for a given GHG were calculated from the EF. The total GHG emissions ( $\mathrm{CO}_{2}$-eq. emissions) (kg) were calculated according to Eq. (1):

$$
\text { Total GHG emissions }=\sum_{x}\left[G W P_{x} * \text { Emissions }_{x}\right]
$$

where $x$ is a given GHG, GWP is the global warming potential of the given GHG, and Emissions are the direct emissions calculated for the given GHG (kg).

The change in GHG emissions between the systems studied were calculated according to Eq. (2) based on five categories (transport, oil, manure, vehicle fuel, and DH) and using two different scenarios: (1) the food company uses the available excess heat to heat the digester and (2) the food company uses part of the biogas produced to heat the digester.

$$
\Delta G H G \text { emissions }=\text { Emissions }_{\text {baseline system }}-\text { Emissions }_{\text {modified system }}
$$

where Emissions baseline system is the annual GHG emissions for the baseline system and Emissions mofidied.system. is the annual GHG emissions for the modified system.

Emissions connected to the use of biomass can be regarded as zero, if the biomass is harvested and regrown without loss of carbon stock [28]. However, if it is not, the emissions connected to the use of biomass must be considered [28]. Calculations have therefore been made for scenarios in which emissions connected with the biomass have been treated as emissions and in which they have all been valued as zero. Table 2 illustrates the settings for which GHG emissions have been analysed. 
Table 2 The settings for which GHG emissions have been analysed.

\begin{tabular}{|l|c|c|c|}
\hline \multicolumn{2}{|c|}{ GHG emissions from biomass } & \multicolumn{2}{c|}{ Zero emissions from biomass } \\
\hline 1) Use of excess heat & 2) Use of biogas & 1) Use of excess heat & 2) Use of biogas to \\
to heat digester & to heat digester & to heat digester & heat digester \\
\hline
\end{tabular}

\subsection{Economic evaluation}

When the total investment cost is unknown, an investment opportunity (IO) can be used in the economic evaluation of an investment. The IO gives a figure of the differences in costs associated with an existing system compared to the costs associated with that system following the investment under discussion; see Eq. (3). A positive value of the IO gives the annual savings potential associated with that investment. That is, calculating the IO offers a way to evaluate how high the cost associated with the systems change could be under current conditions and still remain profitable. Since the IO is given as an annual savings potential, the total IO is company specific due to the different pay-back requirements at different companies.

Economic evaluation based on IO calculations has been used in several previous research studies on energy investments and measures, see for example [29-31]. As a part of the systems analysis in this paper, the opportunity to invest in the biogas production setup discussed in this paper was calculated for the two studied scenarios. A calculation of the IO allowed for a comparison in terms of whether excess heat is used, and this comparison can be used as a tool for judging whether it would be profitable to invest in heat recovery technology. The opportunity to invest production setup for the two scenarios were calculated as the difference in system cost between the systems when the food company does not produce biogas and when is does, according to Eq. (3): 


$$
I O=C_{\text {Food company }}-C_{\text {Food company incl.biogas prod. }}
$$

where $C_{\text {Food company }}$ is the annual system cost for the food company and $C_{\text {Food company incl. biogas }}$ prod. is the annual system cost for the food company if the biogas production facility is built. The calculated IO must cover the actual investment, as well as variable costs associated with the investment, such as costs for operations and maintenance. The annual system cost was calculated as in Eq. (4):

$$
C_{\text {System }}=C_{\text {Fuel (oil) }}+C_{\text {Transport to external biogas plant }}+C_{\text {Transport to WWTP }}
$$

where $C_{\text {Fuel (oil) }}$ is the annual cost of the oil used to produce steam and $C_{\text {Transport to external biogas }}$ plant and $C_{\text {Transport to WWTP }}$ are the annual costs of transporting organic waste to the external biogas plant and the WWTP, respectively.

\section{Calculations and assumptions}

In this section the methods, together with the data retrieved, are applied to the systems studied. The assumptions are also presented in this section.

\subsection{Organic waste and biogas potential}

The total amount of organic waste from the food company is 4830 tons per year (see Table 3). The fluctuations that occur throughout the year can be seen in Figure 2; these result from variations in production during the given year. The potential production of $\mathrm{CH}_{4}\left(\mathrm{Nm}^{3}\right)$ for each substrate has been calculated with Eq. (5):

$$
\mathrm{CH}_{4} \text { production }=\mathrm{TS} *(\mathrm{VS} \text { of } \mathrm{TS}) *\left(\mathrm{CH}_{4} \text { potential }\right) * M
$$


where TS (\%) is the total solids in the substrate, VS of TS (\%) is a measure of the organic matter of the substrate, $\mathrm{CH}_{4}$ potential is the amount of $\mathrm{CH}_{4}$ that could be produced per ton of VS from the substrate ( $\mathrm{Nm}^{3} \mathrm{CH}_{4} /$ ton VS), and $M$ is the total amount of the substrate (ton).

Table 3 Approximate amounts of substrate and potential $\mathrm{CH}_{4}$ production during one year.

\begin{tabular}{|c|c|c|c|c|c|c|c|c|}
\hline Substrates & $\begin{array}{l}\text { Amount of } \\
\text { substrate } \\
\text { (tons/year) }\end{array}$ & \multicolumn{2}{|c|}{ TS (\%) } & \multicolumn{2}{|c|}{$\begin{array}{l}\text { VS of TS } \\
(\%)\end{array}$} & \multicolumn{2}{|c|}{$\begin{array}{l}\text { Specific } \mathrm{CH}_{4} \\
\text { yield }\left(\mathrm{Nm}^{3}\right. \\
\mathrm{CH}_{4} / \text { ton VS ) }\end{array}$} & $\begin{array}{l}\text { Amount of } \\
\mathrm{CH}_{4}\left(\mathrm{Nm}^{3}\right)\end{array}$ \\
\hline Potato & $1060^{\mathrm{a}}$ & \multicolumn{2}{|l|}{$25^{c}$} & \multicolumn{2}{|l|}{$95^{c}$} & \multicolumn{2}{|l|}{$411^{c}$} & 103500 \\
\hline Red beet & $530^{\mathrm{a}}$ & \multicolumn{2}{|l|}{$25^{c}$} & \multicolumn{2}{|l|}{$95^{c}$} & \multicolumn{2}{|l|}{$411^{c}$} & 51800 \\
\hline Fat & $50^{\mathrm{b}}$ & \multicolumn{2}{|l|}{$90^{c}$} & \multicolumn{2}{|l|}{$100^{c}$} & \multicolumn{2}{|l|}{$757^{c}$} & 32400 \\
\hline Pickle liquid & $190^{\mathrm{b}}$ & $100^{\mathrm{d}}$ & $100^{\mathrm{e}}$ & $100^{\mathrm{d}}$ & $100^{\mathrm{e}}$ & $370^{\mathrm{d}, \mathrm{f}}$ & $389^{\mathrm{e}, \mathrm{f}}$ & 14000 \\
\hline Manure & $3000^{b}$ & \multicolumn{2}{|l|}{$8^{c}$} & \multicolumn{2}{|l|}{$80^{c}$} & \multicolumn{2}{|l|}{$268^{c}$} & 51500 \\
\hline Total & 4830 & \multicolumn{2}{|l|}{-} & \multicolumn{2}{|l|}{-} & \multicolumn{2}{|l|}{-} & 253200 \\
\hline
\end{tabular}

${ }^{a}$ Production data ${ }^{b}[32]{ }^{c}[33]^{d}$ Acetic Acid (3.3\%) ${ }^{\mathrm{e}}$ Sucrose $(17 \%)^{\mathrm{f}}[34]$

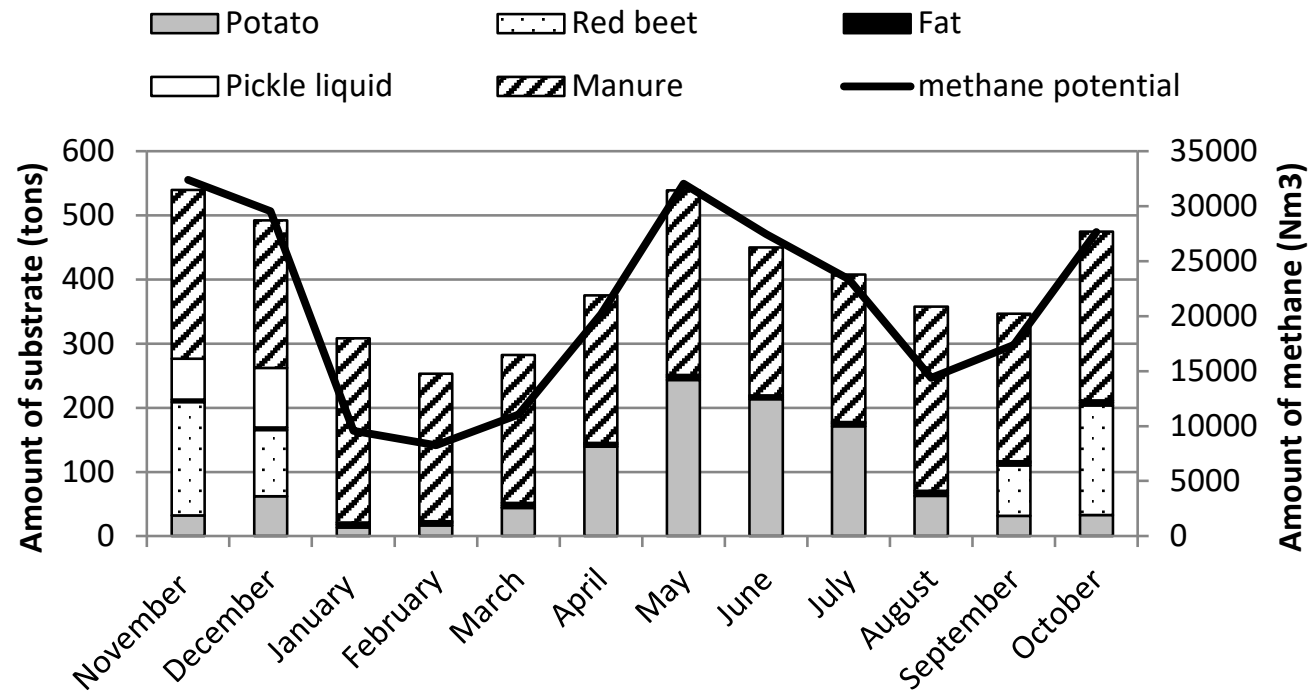

Figure 2 The variations of substrates and the potential amount of $\mathrm{CH}_{4}$ during the studied year. 
Based on analysis of the gas potential for the two root vegetables, the gas potential for red beets was set to the same as that for potatoes. The availability of potato as a substrate follows the demand for potato-based products, while organic waste from red beets is available prior to the demand because red beets are pickled before being used in the final product. It is assumed that the food company uses refined rapeseed oil in the production and that this oil has the same gas yield as deep-frying fat. The availability of fat as a substrate is the same throughout the year [32]. For the pickle liquid the gas potential has been calculated for each of the ingredients (sugar and acetic acid) and then totalled. The availability of pickle liquid as a substrate is highest in November and December. For the rest of the year, the distribution of pickle liquid is even, with a doubling before Easter [32]. For liquid manure, the density is assumed to equal the density of water, due to the low TS content, and the monthly amount is the same throughout the year [32]. The energy potential in the $\mathrm{CH}_{4}$ produced was calculated with the volumetric energy density (36 $\mathrm{MJ} / \mathrm{Nm}^{3}$ ) [35], and sums up to approximately 2500 MWh annually.

The industries in Sweden that have internal production of biogas on site operate the plants at a temperature range of $15^{\circ} \mathrm{C}-45^{\circ} \mathrm{C}$ [14] and hence, a future plant at the food company was assumed to be operating at $37^{\circ} \mathrm{C}$. The heat demand in the digester was set to $0.07 \mathrm{MWh}$ per ton of substrate in line with Berglund and Börjesson [36].

\subsection{Industrial excess heat}

The estimate of excess heat available is based on four main sources excess heat identified: water for boiling potatoes, blanching water, the boiler blow top ${ }^{7}$ water process, and the air compressor.

\footnotetext{
${ }^{7}$ Boiler blow top serves the same purpose as boiler blowdown does, namely, to cleanse the water of impurities. However, the water quality at this location (high lime content) makes boiler blow top more suitable. The process leads to large heat losses.
} 
The size and temperature of the potato boiler $\left(5 \mathrm{~m}^{3}\right.$ and $\left.98^{\circ} \mathrm{C}\right)$ and the blanching tank $\left(2 \mathrm{~m}^{3}\right.$ and $75^{\circ} \mathrm{C}$ ) were obtained during a company visit. The tanks are filled and drained once a day regardless of the number of batches processed. Data regarding the number of boiling days were derived from production data. Small amounts of starch from the potatoes do not notably affect the properties of water and therefore, the density and specific heat capacity of the water were used to calculate the mass of water from potato boiling/blanching and the energy content. It was assumed that the water from both of these sources passed through the same heat exchanger. Since the digester has a temperature requirement of $37^{\circ} \mathrm{C}$, the water temperature following heat exchange to the digester was assumed to be $45^{\circ} \mathrm{C}$ due to the need for a difference in temperature during heat exchange. Based on this temperature and the heat exchanger inlet temperature $\left(98^{\circ} \mathrm{C}\right.$ in potato boiler and $75^{\circ} \mathrm{C}$ in the blanching tank, respectively), a reference temperature of $53^{\circ} \mathrm{C}$ was assumed and then verified by using the heat exchanger software Danfoss Hexact [37]. This temperature was used to calculate the energy that could be transferred to the digester. Based on the tank volume, the water and reference temperatures, and the number of boiling days, the annual excess heat potential from these processes was calculated.

The boiler blow top process runs year around, generating excess heat. The energy logging system provided data regarding the amount of oil used in the boiler. When production is down and there is no need to heat the premises, the oil use originates from the boiler blow top process. Based on production data, it could be concluded that no production occurred on Sundays during the year studied. The outdoor temperature requirements for calculating degree days [38] were used to identify the days on which there was no need for indoor heating (such days were identified during the period May-September). Outdoor temperature data could be 
found in the energy logging system. An average idle energy use could be calculated based on energy data from the days when no production was taking place and no heating was needed (calculations were made from oil use data between the hours of 00:00 and 05:00, on Sundays, May-September). Some $15 \%$ of the input energy content is emitted as flash steam, according to Aronsson [26]. The boiler efficiency was set to 0.77 based on Lindell, Karlsson [25]. Based on the calculated average boiler energy use, the flash steam, and the boiler efficiency, the average energy use under idle conditions was calculated. This energy use originates from the boiler blow top process and constitutes the available excess heat from the process. This excess heat flow was assumed to hold at $90^{\circ} \mathrm{C}$ and be evenly distributed throughout the year. The heat exchanger software Danfoss Hexact was used to estimate the heat exchanger outflow temperature [37]. This temperature was estimated to be approximately $52^{\circ} \mathrm{C}$. Based on the inflow and outflow temperatures, the heat exchanger efficiency was calculated at 0.42 . This efficiency was used to calculate the energy that could be transferred from the boiler blow top water to the digester.

Data on the excess heat potential and temperature of the cooling water from the air compressor were based on the company energy audit. The heat potential was half of the energy supplied, $80 \mathrm{MWh}$ per year, and the temperature of the cooling water was $70^{\circ} \mathrm{C}-80^{\circ} \mathrm{C}$, based on Lindell, Karlsson [25]. This study assumes a temperature of $70^{\circ} \mathrm{C}$, to not overestimate the excess heat potential. The heat is available during production, hence an even distribution during weekdays and throughout the year has been assumed.

\subsection{Environmental assessment}

\subsubsection{Transportation}

If the food company invests in a biogas production unit, a number of shipments will be saved. The fuel consumption has been calculated with the assumption that all transportation is done 
by truck (< 16 tons), involves a fuel consumption of approximately 0.3 litre/km [39], and uses diesel. The emissions (kg) saved by the reduced number of shipments have been calculated for each GHG studied with Eq. (6) [27]:

$$
\text { Emissions }_{G H G, \text { fuel }}=\text { Fuel consumption } \text { fuel } * E F_{G H G, \text { fuel }}
$$

where Fuel consumption is the fuel consumed (TJ), and EF is the emission factor of a given GHG by type of fuel (kg GHG/TJ). The EF for diesel can be found in Table 4.

\subsubsection{Oil}

If the food company starts producing biogas internally, it can replace oil with biogas in the production of steam. Using excess heat to heat the digester allows more oil to be replaced than if biogas is used because some of the biogas is then combusted to cover the heat demand in the digester. Therefore the total amount of biogas combusted is the same, whether it is used to heat the digester or to produce steam for the production processes. The emissions for both cases have been calculated with Eq. (6) [27] (see Table 4 for the EF).

\subsubsection{Manure}

In the modified system, manure from the neighbouring farm is used in biogas production, instead of being spread directly on the field. The emissions of a given GHG (kg GHG/year) associated with spreading manure on fields have been calculated with Eq. (7) [27]:

$$
\text { Emissions }_{G H G}=E F_{G H G} * N
$$


where $E F$ is the emission factor of a given GHG (kg GHG / head, year), and $N$ is the number of pigs (see Table 4 for the EF). It is assumed that the pigs at the farm generate manure that corresponds to that produced by an average of 550 adult $^{8}$ pigs per year.

\subsubsection{Vehicle fuel}

The food waste shipped to the external biogas plant is used to produce biogas through codigestion with other organic wastes from the region. The biogas produced from the anaerobic digestion process is then sold and used as vehicle fuel. If the waste were used instead at an internal biogas plant at the food company, there would be a reduction in the amount of vehicle fuel produced in the region. The vehicle fuel would need to be replaced, presumably with motor gasoline. The emissions for a given GHG (kg/year) have been calculated for both cases with Eq. (6) [27] (see in Table 4 for the EF).

\subsubsection{District heating}

The biogas produced from the waste transported to the WWTP is used in a DH system. If the waste were used instead to produce biogas at the food company, the biogas used in the DH system would need to be replaced. Wood is the major fuel used in the DH system in the region, and an assumption was made that more wood would be used. The emissions of a given GHG (kg/year) for both cases have been calculated with Eq. (6) [27]. The EFs for wood and biogas are found in Table 4.

\subsubsection{Emission factors}

The EFs for the various fuels used in the system and for liquid pig manure are found in Table 4.

\footnotetext{
${ }^{8} 20$ piglets are assumed to generate the same amount of manure as an adult pig.
} 
Table 4 The EFs for diesel, oil, biogas, motor gasoline, wood, and pig manure [27].

\begin{tabular}{|l|l|l|l|}
\hline & $\mathbf{C O}_{2}(\mathbf{k g} / \mathbf{T J})$ & $\left.\mathbf{C H}_{\mathbf{4}} \mathbf{( k g} / \mathbf{T J}\right)$ & $\mathbf{N}_{\mathbf{2}} \mathbf{O}(\mathbf{k g} / \mathbf{T J})$ \\
\hline Diesel & 74100 & 3.9 & 3.9 \\
\hline Oil & 77400 & 3 & 0.6 \\
\hline Biogas $^{\mathrm{a}}$ & 54600 & 1 & 0.1 \\
\hline Pig manure & $0^{\mathrm{b}}$ & $9^{\mathrm{c}}$ & 0 \\
\hline Motor gasoline & 69300 & 25 & 8 \\
\hline Wood $^{\mathrm{a}}$ & 112000 & 30 & 4 \\
\hline
\end{tabular}

${ }^{\mathrm{a}}$ When emissions connected to the biomass are considered as zero emission, all EFs connect to biogas and wood are assumed to be zero ${ }^{\mathrm{b}}$ Net emissions of $\mathrm{CO}_{2}$ are assumed to be zero, in accordance with IPCC [27] ${ }^{\mathrm{c}} \mathrm{kg} / \mathrm{head}$

\subsection{Investment opportunity}

The cost of transporting organic waste to the WWTP and the external biogas plant was based on data from invoices. Currently, the food company bears these costs. No other costs or revenues are associated with the organic waste, so an investment in a biogas plant would mean the company would no longer bear these costs. The amount of biogas produced determines the reduction in the amount of oil needed. The reduced associated cost was based on invoices for oil purchases. An average oil price was calculated (71 EUR/MWh) ${ }^{9}$, based on the quantity of purchased oil, the total oil cost, and subtraction of the tax credit, according to the Swedish taxation system for industrial activities [40]. It was assumed that digestate would replace manure as fertilizer at the farm and there would be no cost or revenue for either product for the food company. This digestate contains more accessible nutrients than manure does [41].

\footnotetext{
${ }^{9}$ Currency conversion: 1 EUR $=9.32$ SEK.
} 


\section{Results}

\subsection{Energy flows}

The total energy content in the $\mathrm{CH}_{4}$ produced (approximately $2500 \mathrm{MWh}$ per year) has been compared to the total oil demand (approximately 6000 MWh per year) at the food company (see Figure 3).

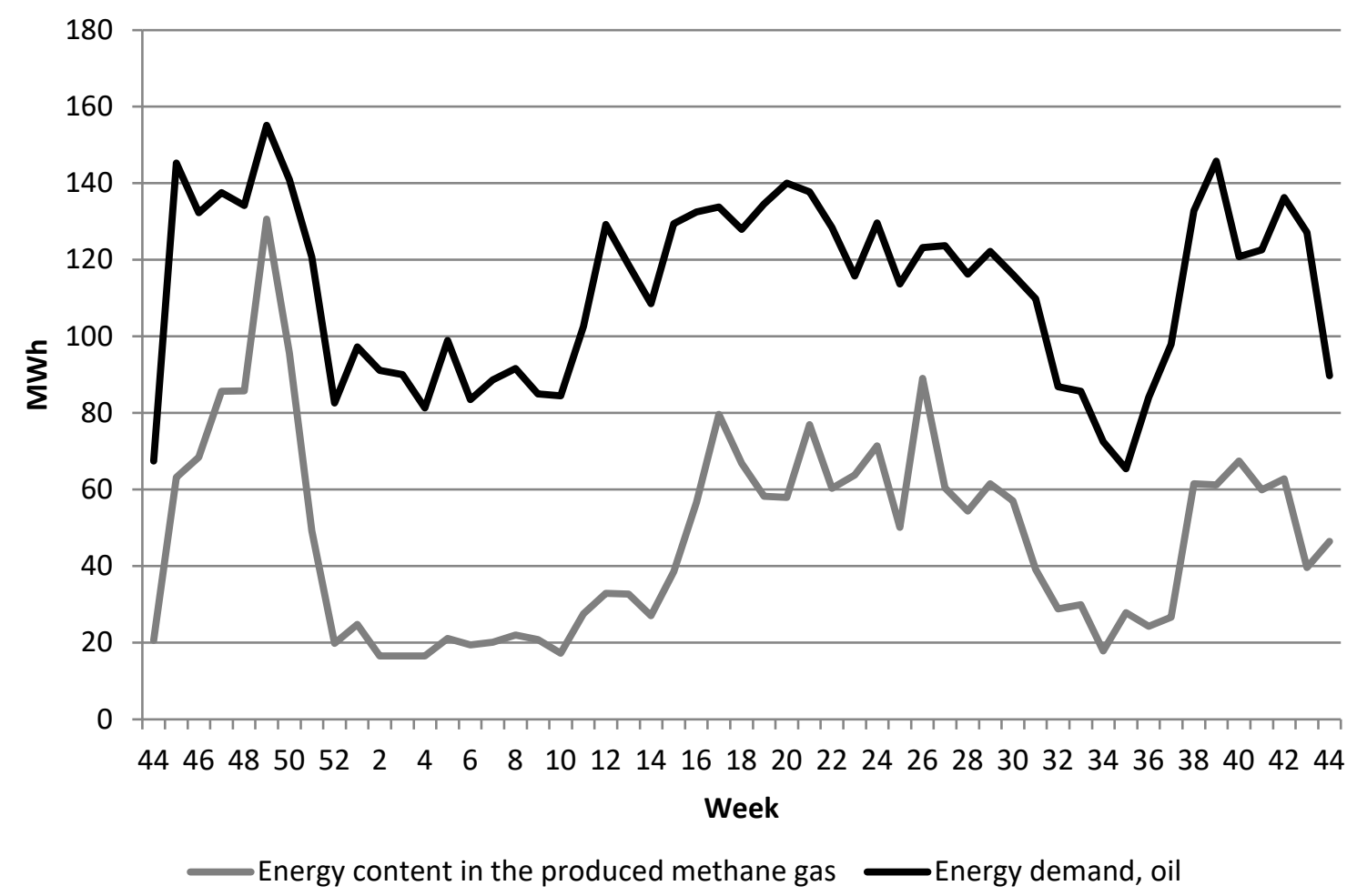

Figure 3 Energy content in the produced gas and the oil demand in the food company.

Figure 3 shows that the energy content in the gas does not fulfil the energy demand at the food company for any part of the year; however, the gas production follows the trend in energy demand throughout the year. In total, $340 \mathrm{MWh}$ per year of heat is needed to heat the digester. The total amount of available excess heat is 1120 MWh per year of which $87 \%$ originates from the boiler blow top process. Figure 4 shows there is a redundancy of excess heat throughout the year, and the demand of the digester is well covered. If excess heat is used 
to heat the digester, the amount of oil that can be replaced with gas is 2530 MWh per year (42\%) and if biogas is used to heat the digester, it is 2200 MWh per year (37\%).

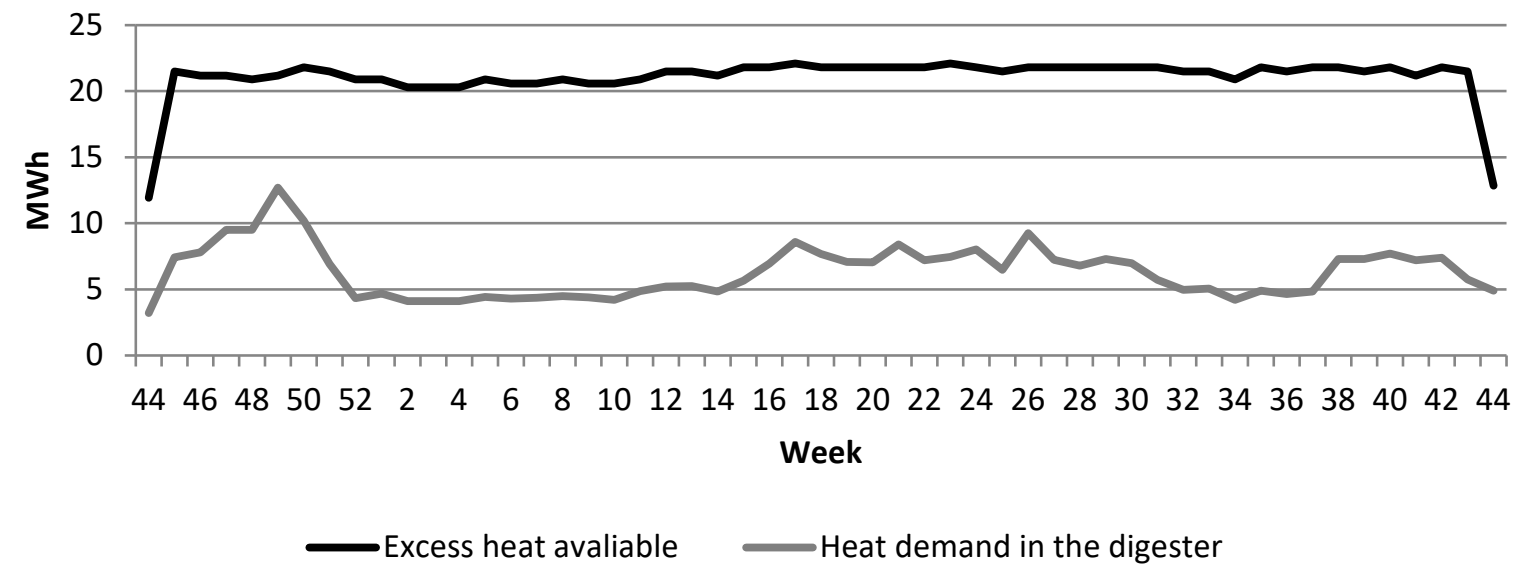

Figure 4 Excess heat available at the food company and the heat demand in the digester.

Since the gas produced does not cover the energy demand at the food company, other fuels are needed to cover the gap. Oil is used today, and therefore, it was assumed that this gap would be filled with oil; hence, not all oil shipments could be eliminated. If excess heat were used to cover the heat demand in the digester (Scenario 1), the reduction in the number shipments would be greater than if biogas were used (Scenario 2) to cover the heat demand in the digester (see Table 5).

Table 5 The shipments and energy that will be saved if the food company invests in a biogas production unit.

\begin{tabular}{|l|l|}
\hline \multicolumn{2}{|l|}{ Transport to WWTP } \\
\hline Distance to WWTP & $64 \mathrm{~km}$ (return journey) \\
\hline Reduction in shipments per year & 51 \\
\hline Reduction km per year & $3264 \mathrm{~km}$ \\
\hline Total energy saved per year & $\mathbf{9 . 5} \mathbf{~ M W h} / \mathbf{y e a r}^{\mathrm{a}}$ \\
\hline Transport to external biogas plant & \\
\hline Distance to the external biogas plant & $80 \mathrm{~km}$ (return journey) \\
\hline
\end{tabular}




\begin{tabular}{|l|l|}
\hline Saved shipments per year & 77 \\
\hline Reduced km per year & $6160 \mathrm{~km}$ \\
\hline Total energy saved & $\mathbf{1 8 . 1}$ MWh/year ${ }^{\mathrm{a}}$ \\
\hline Transport of oil (Scenario 1) & $70 \mathrm{~km}$ (return journey) \\
\hline Distance transportation of oil & 7 \\
\hline Saved shipments per year & $490 \mathrm{~km}$ \\
\hline Reduced km per year & $\mathbf{1 . 4} \mathbf{M W h} /$ year $^{\mathrm{a}}$ \\
\hline Total energy saved & \multicolumn{2}{|l|}{} \\
\hline Transport of oil (Scenario 2) & 70 \\
\hline Distance of oil transportation & 6 \\
\hline Saved shipments per year & 420 km \\
\hline Reduced km per year & $\mathbf{1 . 2 ~ M W h / y e a r ~}$ \\
\hline Total energy saved per year &
\end{tabular}

a The calculations are based on a fuel consumption for trucks ( $<16$ tons) of approximately 0.3 litre $/ \mathrm{km}$ [39].

\subsection{Global $\mathrm{CO}_{2}$ emissions}

The changes in the energy system result in changes in GHG emissions. The global $\mathrm{CO}_{2}-$ equivalent ( $\mathrm{CO}_{2}$-eq.) emissions for the modified system (Figure $\left.1 \mathrm{~B}\right)$ are compared to the baseline system (Figure 1A) and illustrated in Figure 5 (delta $\mathrm{CO}_{2}$-eq. emissions). Internal use of the organic waste for biogas production, in combination with a fuel switch at the food company from oil to biogas, resulted in emission mitigation in both scenarios. When excess heat is used to heat the digester the reduction is, however, almost three times greater than the reduction that occurs when biogas is used (when the EF of the biomass is not zero). This highlights the environmental benefits in terms of $\mathrm{CO}_{2}$-eq. emissions of excess heat use in the system studied. The larger reduction in emissions in the excess heat scenario applies whether or not the biomass is valued with a zero emissions factor. As Figure 5 shows, the 
environmental benefit perceives greater when the biomass is valued with a zero emissions factor than when it is not.

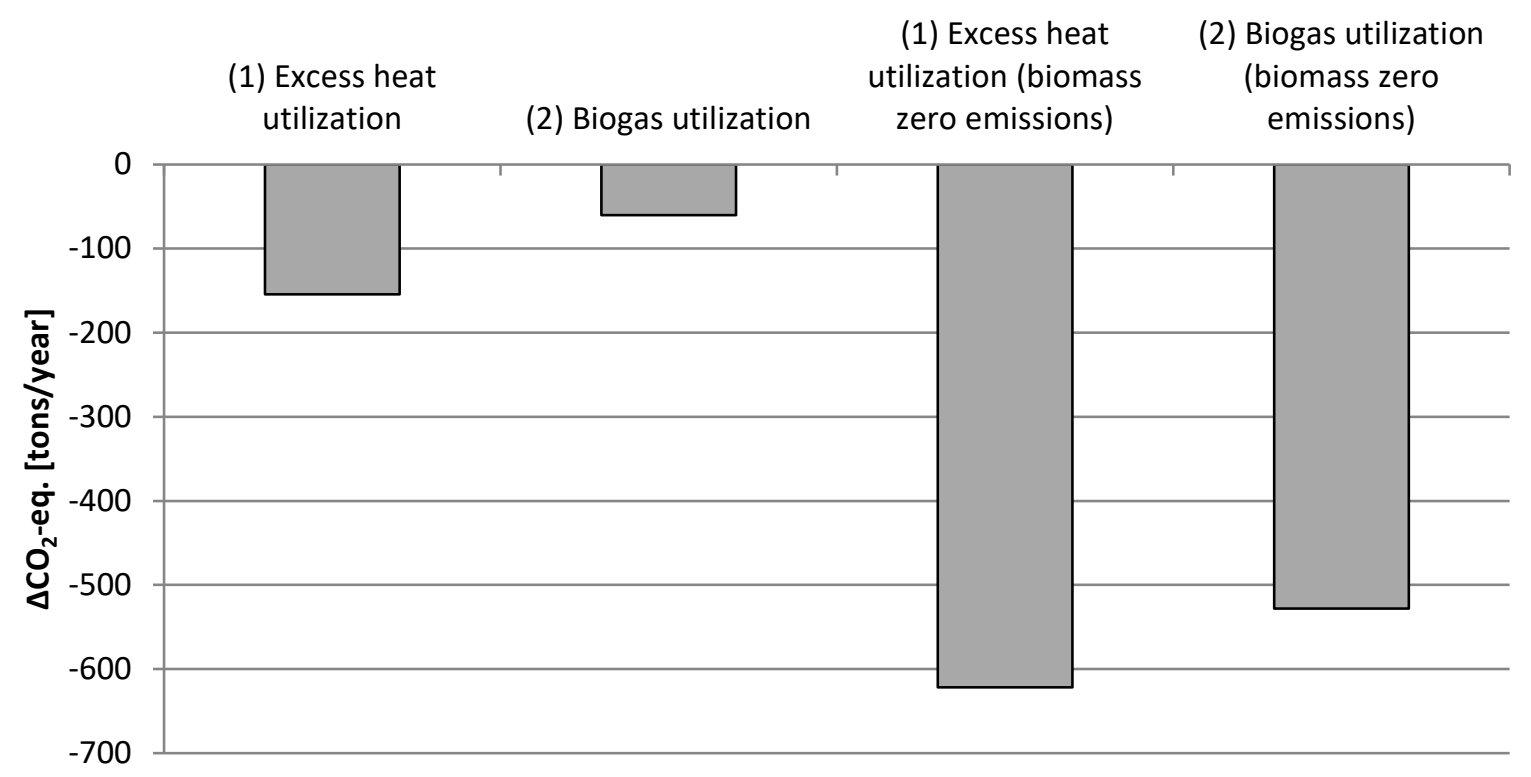

Figure 5 The graph illustrates the delta $\mathrm{CO}_{2}$-eq. emission reductions for the modified system compared to the baseline system.

Even though total emissions are reduced, individual changes in the energy system may result in increased emissions, and Figure 6 illustrates the emissions consequences related to the change in the energy system. The use of motor gasoline as vehicle fuel, wood fuel in the DH system, and biogas in the steam boiler, results in increased emissions. When emissions connected with the biomass have been valued as zero, the use of vehicle fuel is the only factor resulting in increased emissions. But the total reductions decrease because the emissions reduction associated with the reduced use of oil in the steam boiler and the reduced use of biogas as vehicle fuel and as fuel in the DH system, the changed use of manure, and the reduced number of shipments to and from the food company is greater. When the biomass is valued with a zero EF, the changed use of manure, reduced number of shipments, and reduced use of oil in the steam boiler result in a reduction in emissions. As can be seen in Figure 6, the 
reduced use of oil in the steam boiler represents the largest emission reduction, while the emissions from transportation to and from the industrial site are almost negligible.

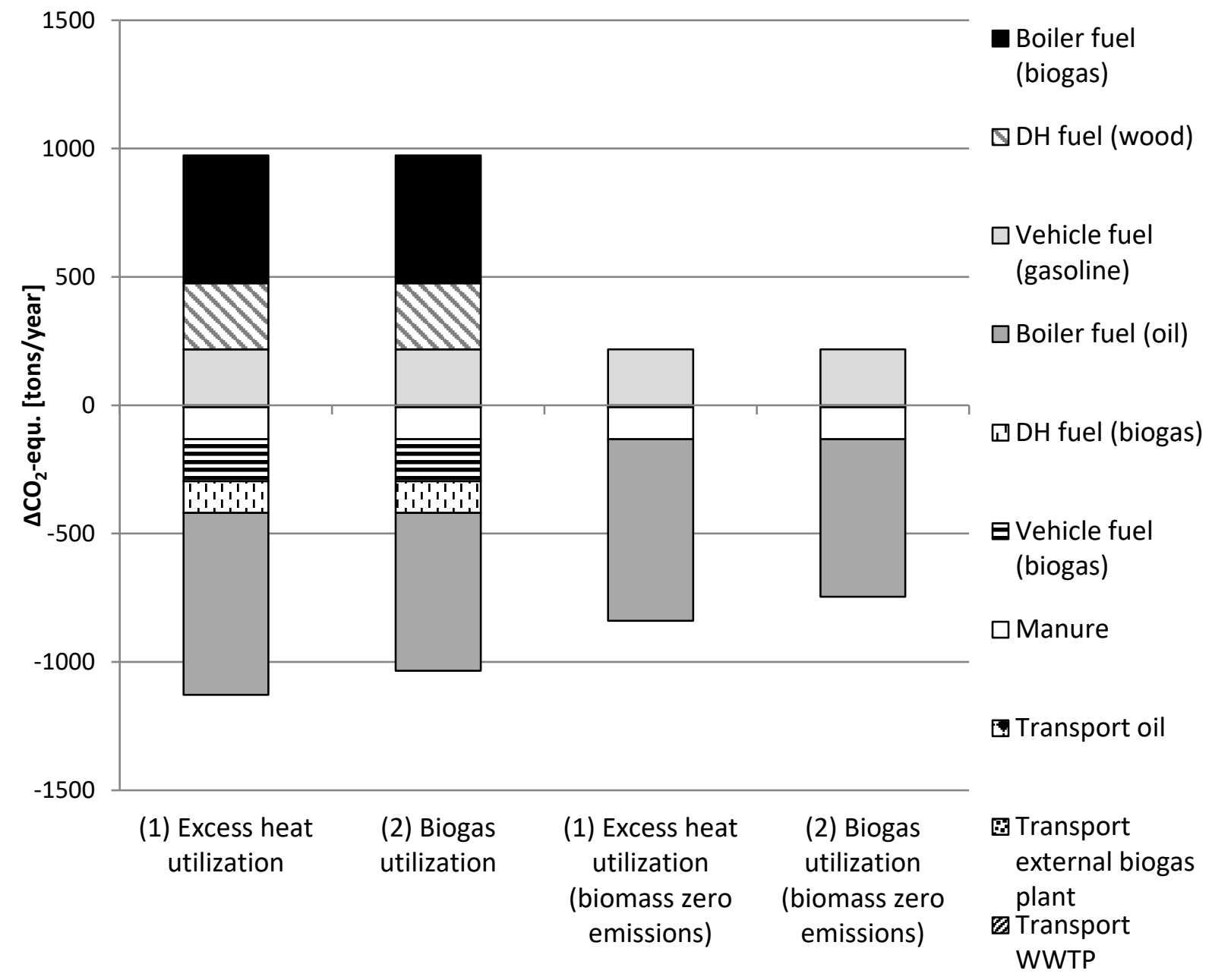

Figure 6 The graph illustrates the origin of the emission changes presented in Figure 5. Bars above 0 are units that have been introduced in the modified system compared to those introduced in the baseline system and vice versa for the bars below 0 .

\subsection{Economic results}

As Figure 7 shows, the food company annual IO for the biogas system ranges between 174 000 and 198000 EUR for the two scenarios. 


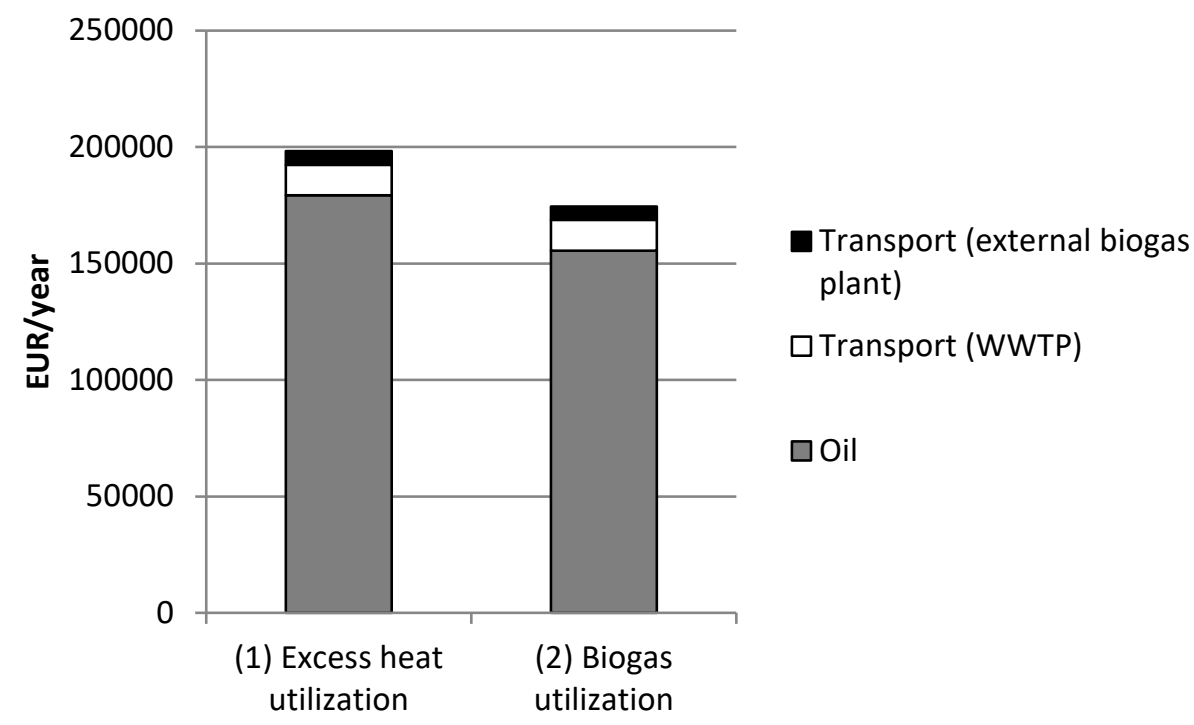

Figure 7 Annual IO for the system if the food company uses its available excess heat to heat the digester or if it uses part of the produced biogas to heat the digester.

The IO is slightly larger if excess heat is used to heat the digester than if biogas is used, which occurs because if excess heat is used to heat the digester, a larger quantity of oil can be replaced with biogas to produce steam during production. As can be seen in Eq. (4), a reduced use of oil reduces the annual system cost; hence, the right term in Eq. (3) is smaller when the available excess heat is used than when it is not. On the other hand, the use of excess heat requires investment in heat recovery equipment.

\section{Concluding discussion}

The aim of this study was to perform a systems analysis to study the effects on GHG and economics when a company changes from using of industrial organic waste for external production of biogas to internal production and use of biogas. The system study demonstrates several possible benefits derived from a synergistic setup. Through cooperation between the industrial and agriculture sectors, more biogas could be produced through co-digestion of industrial organic waste and manure. Thus, while more fossil fuels can be replaced in industry thus reducing the climate impact, agriculture gains a nutritious digestate to spread on fields. 
In addition, if a biogas plant is located close to industrial facilities that hold excess heat, this heat can replace the other fuels normally used to heat the digester. The excess heat potential in this study should be looked upon as a guide for future decisions. It is important not to build a system that depends on heat produced by inefficient energy use. Before the heat is used to heat the digester, it is important to establish an effective industrial energy system in which the heat flows to be used are truly in excess. Bendig, Maréchal et. al. [42] highlight the importance of distinguishing between avoidable and unavoidable excess heat in order not to lock oneself into a system where improved energy efficiency is not possible. As seen in Figure 4, a large redundancy of excess heat remained compared to the heat demand in the digester; thus, significant energy efficiency improvements could be made at the food company and it could still produce enough excess heat to cover the digester's demands. Improved energy efficiency may also reduce the energy demand at the food company, resulting in a better match between the gas produced and the energy demand (shown in Figure 3).

Whether or not the excess heat is used to heat the digester, the total emissions of GHGs will decrease (see Figure 5). However, the reduction is greater if excess heat is used to heat the digester because more oil can be replaced for the production of steam. If emissions related to the biomass are considered zero, the reduction of GHG emissions is greater. This shows that the valuation of biomass has a great impact on how the system is perceived.

The study has shown that this system solution, wherein excess heat instead of biogas is used to heat the biogas digester, is both environmentally (in terms of GHG emissions) and economically advantageous. The positive effects indicate that potential exists for the use of similar systems solutions in other companies and industries. According to Linné, Ekstrandh 
[15], the biogas potential from food industry in Sweden is estimated to be $1790 \mathrm{GWh} / \mathrm{year}$, of which $900 \mathrm{GWh} /$ year is used for purposes other than biogas production. If that potential were used in similar systems, it could contribute to a GHG emission reduction of up to 190000 ton $\mathrm{CO}_{2}$-eq./year (if excess heat is used and emissions connected to the biomass is regarded as zero). This corresponds to $0.4 \%$ of the total GHG emissions in Sweden in 2012 [43].

The circumstances under which this study was performed affect the results. This study, for example, assumed that the food company would fill the gap in energy demand with oil. If another fuel were used, the environmental performance of the system would change, depending on the fuel. As seen in Figure 6, a fuel switch from oil to biogas has a large impact on the environmental performance of the system solution, especially if the emissions connected to the biomass are regarded as zero. A switch from another renewable source to biogas would lead to increased emissions.

All calculations have been performed as if each substrate was digested separately. If codigestion were carried out, the results might differ. The potential amount of gas calculated is the maximum that could be achieved by digestion of the substrates. In reality, storage for the digestate would be needed to collect the maximum amount of gas, since the anaerobic digestion would continue after the digestate have been removed from the digester. It would also be needed because digestate is not needed continuously on farmland and storage of the digestate could be integrated with this additional extraction of gas.

Calculations of the IO are based on the cost associated with oil purchase and the shipment of organic waste and oil. The annual IO presented in Figure 7 must cover the actual investment: e.g. a new boiler, digester, storage for the digestate, ground work and pumps, as well as 
variable costs, such as the cost of operation and maintenance, personnel, and electricity. Since the IO depends mainly on the reduced need to purchase oil, the results depend heavily on oil prices. An increased oil price would increase the IO, while a reduced oil price would reduce the IO. Using excess heat to heat the biogas digester creates a slightly larger IO than that created when biogas is used. Investments associated with the heat recovery, for example, the heat exchanger, pipelines and peripheral equipment would also need to be covered. Thus, the scenario in which excess heat is used has an advantage both environmentally (in terms of GHG emissions) and economically. However, further studies are needed to determine whether it is economically viable to make these additional investments. The Swedish government has presented a proposal [44] regarding financial aid for biogas production based on manure. If the proposal passes, it would positively affect the opportunity to invest in an internal biogas plant at the food company since organic waste is co-digested with pig manure. The opportunity to invest depends on company-specific payback requirements. A payback period of, for example, three years would generate an IO of 523 000-595 000 EUR, depending on whether excess heat is used. An implementation of this system requires several investments. Based on discussions with people within the biogas industry, the investment related to a digester $\left(600 \mathrm{~m}^{3}\right)$ would amount to approximately 200000 EUR. In addition, the IO would need to cover the other investments discussed above.

To conclude, under the circumstances outlined in this study, internal biogas production combined with use of excess heat has environmental and economic benefits. Implementing this synergistic concept in industry will contribute to reaching EU climate targets. 


\section{Acknowledgments}

This work was carried out within the Energy Systems Programme and the Biogas Research Center (BRC). The Energy Systems Programme is funded by the Swedish Energy Agency. BRC is funded by the Swedish Energy Agency, Linköping University, and participating organizations. A special thanks to Jakob Rosenqvist for all his support throughout the work with this paper. We would like to thank Magnus Karlsson, Mats Söderström, Maria Johansson and our colleagues for valuable comments and input. A special thanks to the food company for making this study possible.

\section{References}

[1] European Environment Agency. Trends and projections in Europe 2013 - Tracking progress towards Europe's climate and energy targets until 2020. Report no. 10/2013. European Environment Agency, Copenhagen, Denmark, 2013.

[2] European Commission. Europe 2020: a strategy for smart, sustainable and inclusive growth: communication from the Commission. European Commission, Brussels, 2010.

[3] European Commision. Directive 2012/27/EU of the European Parliament and of the Council on energy efficiency. European Commission, Brussels, 2012.

[4] Broberg, S., Karlsson, M. Systems analysis and $\mathrm{CO}_{2}$ reductions using industrial excess heat. ICAE2013, the fifth international conference on Applied Energy Pretoria, South Africa, 2013.

[5] Broberg Viklund, S., Johansson, M.T. Technologies for utilization of industrial excess heat: Potentials for energy recovery and $\mathrm{CO}_{2}$ emission reduction. Energy Conversion and Management $2014 ; 77$ :369-379.

[6] Campana, F., Bianchi, M., Branchini, L., De Pascale, A., Peretto, A., Baresi, M., Fermi, A., Rossetti, N., Vescovo, R. ORC waste heat recovery in European energy intensive industries: Energy and GHG savings. Energy Conversion and Management 2013;76:244-252.

[7] Thekdi, A., Belt, C. Waste Heat Reduction and Recovery Options for Metals Industry in Energy Technology 2011: Carbon dioxide and other greenhouse gas reduction metallurgy and waste heat recovery. John Wiley \& Sons Inc, 2011.

[8] Chertow, M.R. Industrial symbiosis: literature and taxonomy. Annual review of energy and the environment 2000;25:313-337.

[9] Faith Demirbas, F.M, Balat, M., Balat, H.. Biowastes-to-biofuels. Energy Conversion and Management 2011;52:1815-1828.

[10] Martin, M., Eklund, M. Improving the environmental performance of biofuels with industrial symbiosis. Biomass and Bioenergy 2011;35:1747-1755.

[11] Tufvesson, L.M., Lantz, M., Börjesson, P. Environmental performance of biogas produced from industrial residues including competition with animal feed - life-cycle calculations according to different methodologies and standards. Journal of Cleaner Production 2013;53:214-223. 
[12] Ellersdorfer, M., Weiss, C. Integration of biogas plants in the building materials industry. Renewable Energy 2014;61:125-131.

[13] Traversi, D., Bonetta, S., Degan, R., Villa, S., Porfido, A., Bellero, M., Carraro, E., Gilli, G. Environmental Advances Due to the Integration of Food Industries and Anaerobic Digestion for Biogas Production: Perspectives of the Italian Milk and Dairy Product Sector. BioEnergy Research 2013;6:851-863.

[14] Paulsson, J., Steinwig, C. Production and use of biogas 2012 [Produktion och användning av biogas 2012]. Swedish Energy Agency, 2013. [In Swedish]

[15] Linné, M., Ekstrandh, A., Engelsson, R., Persson, E., Björnsson, L., Lantz, M. The Swedish biogas potential from domestic residues [Den svenska biogaspotentialen från inhemska restprodukter]. BioMill and Envirum AB, 2008. [In Swedish]

[16] Lantz, M., Svensson, M., Björnsson, L., Börjesson, P. The prospects for an expansion of biogas systems in Sweden - Incentives, barriers and potentials. Energy Policy 2007;35:18301843.

[17] Jorgensen, P.J. Biogas - green energy. 2 ed. Faculty of Agricultural Sciences, Aarhus University, 2009.

[18] Weiland, P. Biogas production: current state and perspectives. Applied Microbiology and Biotechnology 2010;85:849-860.

[19] Demirbas, A.. Biofuels sources, biofuel policy, biofuel economy and global biofuel projections. Energy Conversion and Management 2008;49:2106-2116.

[20] Vindis, P., Mursec, B., Janzekovic, M., Cus, F. The impact of mesophilic and thermophilic anaerobic digestion on biogas production. Journal of achievements in materials and manufacturing Engineering 2009;36:192-198.

[21] Deublein, D., Steinhauser, A. Biogas from Waste and Renewable Resources: An Introduction. John Wiley \& Sons, 2011.

[22] Nyström, I., Franck, P.Å. Presence of industrial excess heat at low temperatures [Förekomst av industriellt spillvärme vid låga temperaturer]. CIT Industriell Energianalys, 2002. [In Swedish]

[23] Ammar, Y., Joyce, S., Norman, R., Wang, Y., Roskilly, A.P. Low grade thermal energy sources and uses from the process industry in the UK. Applied Energy 2012;89:3-20.

[24] Churchman, C.W. The Systems Approach. Delacorte Press, New York, USA, 1968.

[25] Lindell, W., Karlsson, P., Gille, T. Energy audit at a Swedish food company 2010 [Energikartläggning av ett svenskt livsmedelsföretag 2010]. Industriell Laststyrning, Sweden, 2011. [In Swedish]

[26] Aronsson, M. Recycling solution boiler room [Återvinningslösning pannrum]. Spriax Sarco AB, Sweden, 2010. [In Swedish]

[27] IPCC. 2006 IPCC Guidelines for National Greenhouse Gas Inventories. in: Eggleston, H.S., Buendia, L., Miwa, K., Ngara, T., Tanabe, K., (Eds.), National Greenhouse Gas Inventories Programme, IGES, Japan, 2006.

[28] Watson, R.T., Noble, I.R., Bolin, B., Ravindranath, N., Verardo, D.J., Dokken, D.J. Land use, land-use change and forestry. IPCC (Intergovernmental Panel on Climate Change), 2000.

[29] Bengtsson, C., Karlsson, M., Berntsson, T., Söderström, M. Co-ordination of pinch technology and the MIND method - applied to a Swedish board mill. Applied Thermal Engineering 2002;22:133-144.

[30] Heyne, S., Harvey, S. Assessment of the energy and economic performance of second generation biofuel production processes using energy market scenarios. Applied Energy 2013;101:203-212.

[31] Wetterlund, E., Pettersson, K., Harvey, S. Systems analysis of integrating biomass gasification with pulp and paper production - Effects on economic performance, $\mathrm{CO}_{2}$ emissions and energy use. Energy 2011;36:932-941. 
[32] Personal communication with the food company - Environmental manager. 2013.

[33] Carlsson, M., Uldal, M. Substrate handbook for biogas production [Substrathandbok för biogasproduktion]. Report no. SGC 200. Swedish Gas Technology Centre, 2009. [In Swedish] [34] Angelidaki, I., Karakashev, D., Batstone, D.J., Plugge, C.M., Stams, A.J. Biomethanation and its potential. Methods Enzymol 2011;494:327-351.

[35] Cuéllar, A.D., Webber, M.E. Cow power: the energy and emissions benefits of converting manure to biogas. Environmental Research Letters 2008;3.

[36] Berglund, M., Börjesson, P. Assessment of energy performance in the life-cycle of biogas production. Biomass and Bioenergy 2006;30:254-266.

[37] Danfoss. Danfoss Hexact. Version 1.5.7b. Access date 2014-01-13. 2014.

[38] Adalberth, K., Wahlström, Å. Energy audits in buildings; appartment buildings and premises [Energibesiktning av byggnader: flerbostadshus och lokaler]. SIS Förlag, Sweden, 2009. [In Swedish]

[39] U. Hammarström, M.-R. Yahya. Estimation of representative fuel elements for heavy trucks [Uppskattning av representativa bränslefaktorer för tunga lastbilar]. VTI (The Swedish National Road and Transport Research Institute), Sweden, 2000. [In Swedish]

[40] Skatteverket. Taxes - Industrial activity [Skatter - Industriell verksamhet]. Access date 2014-03-27. 2014. [In Swedish]

[41] Baky, A., Nordberg, Å., Palm, O., Rohde, L., Salomon, E. Digestate from biogas production plant - use in agriculture [Rötrest från biogasanläggningar - användning i lantbruket]. JTI (Swedish Institute of Agricultural and Environmental Engineering), Sweden, 2006. [In Swedish]

[42] Bendig, M., Maréchal, F., Favrat, D. Defining "Waste Heat" for industrial processes. Applied Thermal Engineering 2013;61:134-142.

[43] Swedish Environmental Protection Agency. National Greenhouse gas emissions 19902012 [Nationella utsläpp av växthusgaser 1990-2012]. Acess date 2014-09-22. 2014. [In Swedish]

[44] Ministry of Rural Affairs. From manure to biogas in a new pilot study [Från gödsel till biogas i nytt pilotprojekt]. Access date 2014-04-26. 2013. [In Swedish] 